\title{
RESEARCH PAPER \\ PRELIMINARY MONITORING OF FAECAL INDICATOR ORGANISMS OF SURFACE WATER: A CASE STUDY OF MVUDI RIVER, SOUTH AFRICA
}

\author{
J. N. Edokpayi* ${ }^{1}$, J. O. Odiyo ${ }^{1}$, T. A. M. Msagati ${ }^{2}$ and N. Potgieter ${ }^{3}$ \\ ${ }^{I}$ Department of Hydrology and Water Resources, University of Venda, South Africa \\ ${ }^{2}$ Nanotechnology and Water Sustainability Research Unit, Florida Science Campus, \\ University of South Africa, South Africa, \\ ${ }^{3}$ Department of Microbiology, University of Venda, South Africa \\ *Corresponding author: joshuanedos@gmail.com
}

\begin{abstract}
Faecal contamination of water bodies is a known cause of high morbidity in developing countries. This study was carried out to assess the level of faecal contamination in Mvudi River used as a source of domestic water for people who live around it. Certified multimeters were used to measure $\mathrm{pH}$, conductivity and turbidity while membrane filtration technique was employed to test for E. coli and total Enterococci in 18 water samples collected during sampling from January to March, 2014. The pH and conductivity values obtained varied between 7.30-7.88 and 10.47-15.94 $\mathrm{mS} / \mathrm{m}$ respectively. Turbidity values were in the range of 17.57 and $429 \mathrm{NTU}$. $E$. colicounts were in the range of 950-11,533 cfu/100 $\mathrm{mL}$ while total Enterococci varied between 1,650-4,767 cfu/100 $\mathrm{mL}$. The $\mathrm{pH}$ and $\mathrm{EC}$ data determined complied with the guideline values of the Department of Water Affairs and Forestry of South Africa (DWAF) and the World Health Organization (WHO) for domestic water use, but turbidity, E. coli and total Enterococci levels exceeded these guideline values. Mvudi River is microbiologically unfit and should not be used for drinking, domestic and recreational purposes without proper treatment.
\end{abstract}

Keywords: Contamination, faecal indicator, organisms, surface, domestic water

\section{INTRODUCTION}

Surface water is one of the most influenced ecosystems on earth. Its alterations have led to an extensive ecological degradation such as decline in water quality and availability, intense flooding, loss of species and changes in the distribution and structure of the aquatic biota thus making them no longer sustainable in providing goods and services (Poff et al., 1997).
The health of a river system is influenced by various factors, which include the geomorphology and geological formations, the chemical, physical and biological quality of the water (Poff et al. 1997).

Access to safe drinking water is a basic need for human growth and economic development, although essential for all life forms (WHO/ 


\section{Edokpayi et al.}

UNCIEF, 2010).More than one billion people in the world do not have access to safe drinking water (WHO/UNCIEF, 2010; UNDP, 2006). The use of surface water for domestic and other purposes has been the norm particularly in rural areas where there in either lack or insufficient potable water (Obi et al., 2002). The quality of surface water sources is continuously threatened by several anthropogenic activities, ranging from the effluent of wastewater treatment facilities to surface runoff from agricultural lands. Scarcity of potable water has been positively correlated with several water borne diseases. Meanwhile people, mostly residents of rural areas, are forced to consume untreated water (Obi et al. 2002).

The microbial quality of surface water has received more attention than the physical and chemical water quality parameters because of the immediate negative effects they have on the health of man and other living organisms. The use of contaminated water for domestic purposes has been linked to several episodes of disease outbreak mostly in developing countries of the world. Access to improved water sources in South Africa is at 94\% (Department of Water Affairs, 2012); however, most rural areas still face challenges of accessing safe drinking water. (Muthamba, 2014).

The South African government has been working tirelessly to provide potable water for her citizens but this has been hampered in a number of ways ranging from inadequate water specialists working in rural areas to low service delivery at the Municipal level. This study was undertaken to assess the microbial quality of the Mvudi River, which is used for domestic purposes, agricultural and recreational purposes and also serves as a major source of water to Nandoni Dam. Mvudi River is located on the geographical co-ordinates E030 27'59.3", E030 $28^{\prime} 46.0^{\prime \prime}$ and S22 59'37.5", S23 ${ }^{\circ} 00^{\prime} 10.4^{\prime \prime}$ (Fig.1). Informal settlements, subsistence agriculture and waste disposal sites form major land uses within the river catchment.

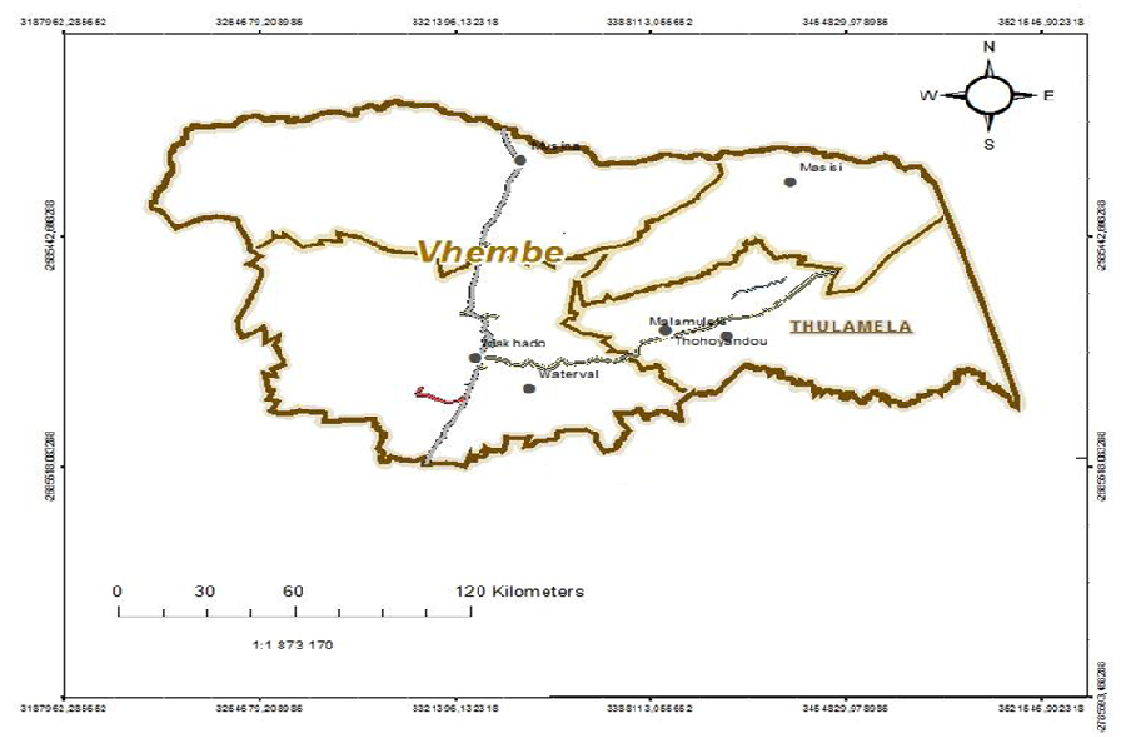

Fig. 1: Map of study area 
MATERIALS AND METHOD

Sampling and Analysis

The sampling of water was done at subsurface level $(0-5 \mathrm{~cm})$ along various points of Mvudi River. The samples were placed in a cooler box with ice and analysed within 6 hours of collection in the Microbiological Laboratory of the University of Venda, South Africa. $100 \mathrm{~mL}$ of the sample was filtered with a $0.45 \mu \mathrm{m}$ pore size, and a $47 \mathrm{~mm}$ diameter Millipore filter membrane. E. coli and total Enterococci were cultured and enumerated on $\mathrm{mFC}$ and enterococcus agar (supplied by Merck pty Ltd, South Africa) after 24 and 48 hours of incubation, respectively (APHA, 1992). $\mathrm{pH}$ and conductivity of the water samples were measured with certified multimeter, while turbidity measurements were performed with a turbidimeter.

\section{RESULTS AND DISCUSSION}

\section{Physico-chemical parameters}

$\mathrm{pH}$ of Mvudi River varied from 7.30-7.66 (Table 1) and did not exceed the specified $\mathrm{pH}$ limits for domestic water by DWAF and WHO (6-9.5) (DWAF, 1996 and WHO, 2006). The $\mathrm{pH}$ of a river plays an important role in the bioavailability of metals for aquatic organisms. Most metals are bioavailable at lower $\mathrm{pH}$ but precipitate as insoluble substance at higher $\mathrm{pH}$ (Edokpayi et al., 2014). Conductivity of the river usually shows their tendency to conduct electricity due to the presence of dissolved ions. The conductivity values ranged between 10.47 $\mathrm{mS} / \mathrm{m}$ and $15.94 \mathrm{mS} / \mathrm{m}$ and fell within the threshold guideline values of 70 and $600 \mathrm{mS} / \mathrm{m}$ by DWAF (1996) and WHO (2006). Turbidity values were highest in January (429 NTU), which corresponds to the period of highest precipitation in the study area but were lower in the other months. The turbidity values obtained exceeded the recommended level of drinking water (DWAF, 1996; WHO, 2006).

\section{Microbiological parameters}

Enterococci and Escherichia coli (E. coli) have been continuously used for the assessment of the quality of water used for domestic and recreational purposes worldwide (Korajkic et al. 2013).E. coli count was lowest in February and highest in March (Fig. 2) while enterococci counts were highest in January and lowest in March. The levels of E. coli obtained did not vary significantly between the three months investigated $(\mathrm{P}>0.05)$. Significant variations were recorded for enterococci counts between the sampling months of January and February $(p<0.02)$ and January and March $(\mathrm{p}<0.02)$. However, the levels determined in February and March did not differ significantly. The mean levels of $E$. coli recorded from JanuaryMarch, were $1933 \mathrm{cfu} / 100 \mathrm{~mL}, 950 \mathrm{cfu} / 100 \mathrm{~mL}$ and $11533 \mathrm{cfu} / 100 \mathrm{~mL}$, respectively. These levels were higher than the recommended guideline of DWAF and WHO for various water use (DWAF 1996; WHO 2006). Similarly, the mean levels of enterococci were in the range of 1650-4767 cfu/100 mL (Fig. 3) and were beyond the threshold guidelines values of DWAF and WHO (DWAF 1996; WHO 2006). The consumption of water from this source could possibly be of risk to animals and humans. The river water should not be used to rinse vegetables like carrots and cabbage eaten raw by people as this could be a health risk to the consumers.

Table 1: Results of physico-chemical parameters

\begin{tabular}{lccc}
\hline Sampling Months & January & February & March \\
\hline $\mathrm{pH}$ & $7.38 \pm 0.04$ & $7.3 \pm 0.04$ & $7.66 \pm 0.16$ \\
Conductivity (mS/m) & $10.47 \pm 0.08$ & $15.94 \pm 0.66$ & $13.57 \pm 1.8$ \\
Turbidity (NTU) & $429 \pm 31.3$ & $20.39 \pm 4.3$ & $17.57 \pm 8.2$ \\
\hline
\end{tabular}




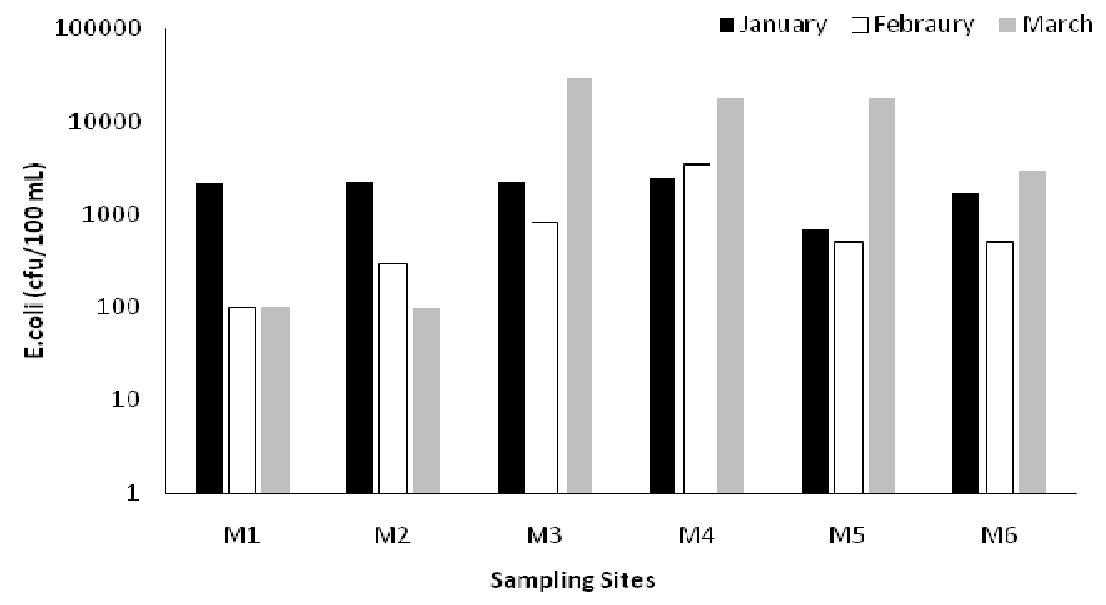

Fig. 2: $E$. coli counts in the sampling sites of Mvudi River

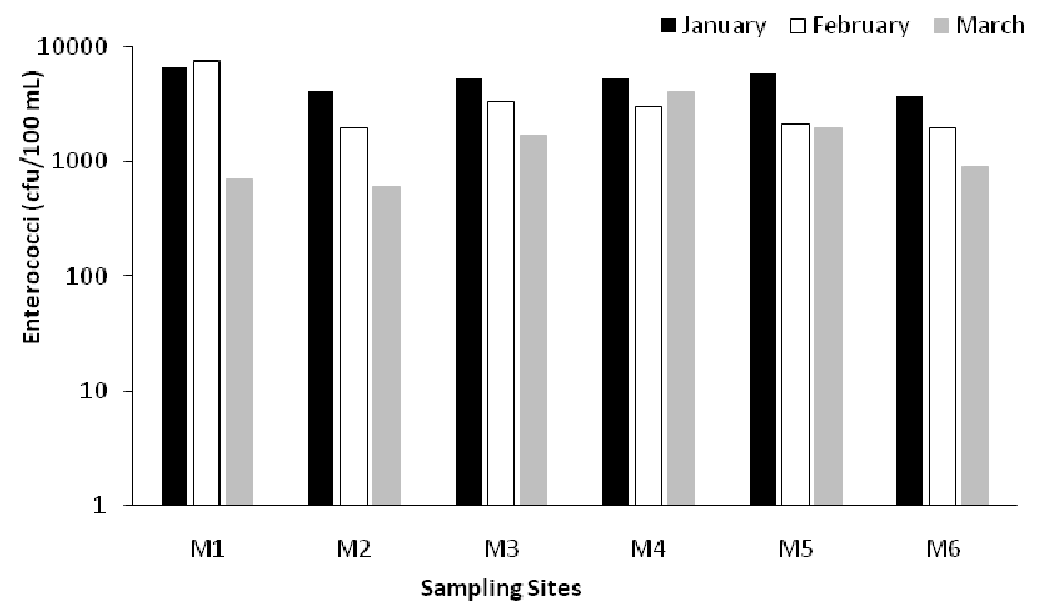

Fig. 3: Total Enterococci counts in the sampling sites of Mvudi River

\section{CONCLUSION}

The levels of feacal coliforms put together for each of the sampling months exceeded the guideline values for domestic water use. Water from Mvudi River is contaminated with faecal organisms and should not be used without disinfection. The $\mathrm{pH}$ and conductivity levels fell within the benchmark values while turbidity levels were above the recommended level of $<1$ NTU.

\section{REFERENCES}

American Public Health Association (APHA, 1992). Washington, DC, USA, 1992,APHA. Standard Methods for the Examination of Water and Wastewater, 18th ed. 
Report, 1 April 2011 - 31 March 2012. DWA, Pretoria.

Department of Water Affairs and Forestry (DWAF). (1996) South African water quality guidelines, Vol, 1: Domestic Water Use, Second Edition.

Edokpayi, J. N., Odiyo, J. O. and Olasoji, S. O. (2014).Assessment of heavy metal contamination of Dzindi River, in Limpopo Province, South Africa, International Journal of Natural Science Research, 2(10):185-194.

Korajkic, A, McMinn, B. R., Harwood,V. J., Shanks, O. C., Fout, G. S and Ashbolt, N. J. (2013). Differential Decay of Enterococci and Escherichia coli Originating from Two Fecal Pollution Sources. Applied and Environmental Microbiology, 79(19):2488-2492.

Mutamba, J. (2014).Meeting Rural Water Supply Challenges: Lessons from a South African Groundwater Supply Scheme, Recent Advances in Environmental Science and Geoscience 56-61, ISBN: 978-1-61804-2248 , In Proceedings of the 2014 International Conference on Environmental Science and Geoscience (ESG '14). Accessed January 13,
2015.

Obi, C. L., Potgieter, N., Bessong, P.O. and Matsaung, G. (2002). Assessment of the microbial quality of river water sources in rural Venda communities in South Africa. Water S.A. 28(3): 287-292

Poff, L. N., Allan, D., Bain, M. B., Karr, J. R., Prestegaard, K. L., Richter. B. D., Sparks, R. E. and Stromberg, J. C. (1997). The natural flow regime: A paradigm for river conservation and restoration. Bioscience,47(11):769784 .

UNDP, (2006). Human Development Report, beyond scarcity: Power, poverty and the global water crisis. United Nations Development Programme, New York.

WHO, (2006). Guidelines for drinking-water quality first addendum to 3rd edition, In Recommendations, WHO: Geneva, Switzerland, Vol. 1.

WHO/UNICEF, (2010). Progress on sanitation and drinking water - 2010update, WHO Library Cataloguing-in-Publication Data. 